\title{
KARAKTERISTIK NORI DARI CAMPURAN RUMPUT LAUT Ulva lactuca DAN Gelidium sp.
}

\author{
Gisella Valentine, Sumardianto, Ima Wijayanti* \\ Program Studi Teknologi Hasil Perikanan Jurusan Perikanan, Fakultas Perikanan dan Ilmu Kelautan, \\ Universitas Diponegoro, Jalan Prof. Soedarto, SH Tembalang, Semarang 50275 Jawa Tengah \\ Telepon/Fax +6224 7474698 \\ *Korespondensi: imasetianto@gmail.com \\ Diterima: 03 Juni 2019/ Disetujui: 07 Juli 2020
}

Cara sitasi: Valentine G, Sumardianto, Wijayanti I. 2020. Karakteristik nori dari rumput laut Ulva lactuca dan Gelidium sp. Jurnal Pengolahan Hasil Perikanan Indonesia. 23(2): 295-302.

\begin{abstract}
Abstrak
Nori merupakan produk pangan yang dihasilkan dari rumput laut Phorphyra. Phorphyra tidak tersedia di Indonesia sehingga upaya membuat produk nori dapat digunakan rumput lain yang tersedia melimpah di Indonesia antara lain Ulva lactuca dan Gelidium. Ulva lactuca mengandung klorofil yang dapat memberi kontribusi warna hijau pada nori. Gelidium merupakan penghasil agar yang dapat berfungsi sebagai pengemulsi, bahan pemantap, pengental, penstabil, penjernih dan pembentuk gel. Kombinasi dua rumput laut tersebut diduga dapat menghasilkan nori dengan karakteristik mendekati produk komersial. Penelitian ini bertujuan menguji pengaruh perbandingan jumlah Ulva lactuca dan Gelidium terhadap nilai hedonik, kuat tarik, serat kasar, kadar protein, air dan abu. Tiga perlakuan perbandingan persentase Ulva lactuca dan Gelidium digunakan yaitu 75\%:25\% (P1); 50\%:50\% (P2); dan 25\%:75(P3). Perbandingan persentase Ulva lactuca dan Gelidium berpengaruh nyata $(p<0,05)$ terhadap nilai sensori (hedonik), kuat tarik, kandungan serat kasar, kadar protein dan abu, namun tidak berpengaruh nyata $(p>0.05)$ terhadap jumlah kadar air nori. Perlakuan P1 (75\% Ulva lactuca dan 25\% Gelidium) adalah nori yang paling disukai panelis dan mempunyai karakteristik warna hijau tua, mudah dilipat, tipis, memiliki tekstur yang halus dan rasa asin, mendekati nori komersial dengan nilai hedonik $7,26<\mu<7,41$. Nori P1 menghasilkan nilai kuat tarik; kandungan serat kasar; kadar air; kadar protein dan abu masing-masing 4,65 $\pm 1,5 \mathrm{Mpa} ; 20,44 \pm 1,78 \%$, $17,24 \% \pm 0,57 ; 12,89 \pm 0,07 \%$ dan $14,71 \pm 0,09$.
\end{abstract}

Kata kunci : Gelidium, nori, karakteristik, Ulva lactuca

\section{Characteristic of Nori from Combination of Ulva lactuca and Gelidium Seaweed}

\begin{abstract}
Nori is a food product produced from Phorphyra seaweed, however, this seaweed is not available in Indonesia. Thus modification of nori production by using available seaweed such as Ulva lactuca and Gelidium is needed. U. lactuca contains chlorophyll which can contribute to the nori's green color while Gelidium can become an emulsifier, stabilizer, thickener, stabilizer, purifier, and gel maker. The combination of the two seaweeds is expected to produce nori with characteristics close to commercial products. This study was aimed to examine the effect of different ratio of Ulva lactuca and Gelidium on hedonic values, tensile strength, crude fiber, protein, water, and ash content of nori. Three ratios of Ulva lactuca and Gelidium were used comprising P1 (75\%: 25\%), P2 (50\%: 50\%), and P3 (25\%: 75). The ratios of U. lactuca and Gelidium significantly affected $(p<0.05)$ sensory value (hedonic), tensile strength, crude fiber, protein and ash content, but not water content. The P1 treatment nori was preferred by the panelists with a hedonic value of $7.26<\mu<7.41$ and had the characteristics of dark green color, easily folded, thin, smooth texture and salty taste, similar to commercial nori. The P1 Nori had tensile strength values $4.65 \pm 1.5 \mathrm{MPa}$; crude fiber20.44 $\pm 1.78 \%$; water $17.24 \pm 0.57 \%$, protein $12.89 \pm 0.07 \%$ and ash content $14.71 \pm 0.09 \%$.
\end{abstract}

Keywords: Gelidium, nori, characteristic, Ulva lactuca 


\section{PENDAHULUAN}

Ulva lactuca merupakan salah satu jenis alga hijau yang termasuk dalam rumput laut yang dapat dimakan, memiliki kandungan antioksidan, antibakteri, antijamur dan antitumor (Arbi et al. 2016). Gelidium merupakan salah satu rumput laut penghasil agar yang memiliki pelekap (holdfast) sebagai tempat melekat di karang, blades atau talus pipih. Murdinah et al. (2008) menjelaskan bahwa Gelidium merupakan sumber bahan baku yang lebih disukai untuk ekstraksi agar karena kekuatan gel yang dihasilkan relatif tinggi dengan kadar sulfat yang rendah. Pengembangan produk berbasis rumput laut merupakan salah satu cara dalam memaksimalkan pemanfaatannya. Rumput laut bisa dimanfaatkan menjadi produk berupa jeli (Rismandari et al. 2017; Fajarini et al. 2018), agar-agar (Dewi 2012; Anton 2017; Abraham et al. 2018) dan nori (Zakaria et al. 2017; Kurniawan dan Bintoro 2019; Abdullah et al. 2019).

Nori merupakan makanan tradisional Jepang berbentuk lembaran tipis yang dibuat dengan cara menghaluskan, membumbui dan mengeringkan rumput laut jenis phorphyra. Nori memiliki tekstur kering dan renyah dengan rasa asin dan khas rumput laut. Jenis rumput laut yang sering digunakan untuk membuat nori adalah jenis phorphyra yang tidak tumbuh di wilayah Indonesia. Nori perlu dikembangkan dengan menggunakan rumput laut lokal yang cukup melimpah di perairan Indonesia seperti U. lactuca dan Gelidium. Ulva. lactuca telah dimanfaatkan dalam pembuatan garam rumput laut (Nufus et al. 2017; Nurjanah et al. 2018; Kurniawan et al. 2019), kombinasi U. lactuca dan Gelidium juga sudah sudah dilakukan dalam pembuatan geluring yang memiliki kadar klorofil a, klorofil b dan karotenoid serta mampu menurunkan residu logam berat (Erniati et al. 2018).

Kajian tentang pembuatan nori dari rumput laut yang tersedia di Indonesia sudah dilakukan, namun masih terbatas. Studi tentang nori dari beberapa rumput laut yang tersedia di Indonesia antara lain $U$. lactuca dan E. cottonii (Zakaria et al. 2017), campuran U. lactuca dan Gracilaria (Kurniawan dan
Bintoro 2019); Sargassum dan Euchema spinosum (Faris et al. 2019), Gracilaria dengan campuran tepung belut (Fitrah et al. 2019), Gelidium dan E. cottonii (Abdullah et al. 2019). Pembuatan nori bukan dari spesies Porphyra menunjukkan hasil kurang optimal apabila hanya diproduksi dari satu jenis rumput laut. Kombinasi dua rumput laut diharapkan mampu menghasilkan nori dengan kualitas yang mendekati produk komersial. U. lactuca merupakan rumput laut dengan warna hijau tua dan Gelidium merupakan penghasil agar (Lebbar et al. 2018; Hussein 2015) yang dapat dibentuk menjadi lembaran sebagaimana produk nori.

Abdullah et al. (2019) menyatakan pembuatan nori dari Gelidium saja kurang sukses dalam membuat produk nori, namun kombinasi dengan beberapa rumput laut dapat menghasilkan produk yang mendekati nori komersial. Kajian tentang pembuatan nori dari rumput laut U. lactuca dan Gelidium belum pernah dilakukan. Tujuan dari penelitian ini adalah untuk menguji pengaruh perbandingan U. lactuca dan Gelidium terhadap karakteristik nori serta menentukan rasio terbaik antara U. lactuca dengan Gelidium dalam pembuatan nori dikaji dari karakteristik kimia, fisika, dan sensori.

\section{BAHAN DAN METODE Bahan dan Alat}

Bahan utama yang digunakan adalah U. lactuca dan Gelidium yang diperoleh dari pantai di daerah Gunung Kidul Yogyakarta. Bahan tambahan berupa garam, bawang putih, saus tiram, dan minyak wijen. Alat yang digunakan dalam pembuatan nori adalah baskom, pisau, talenan, gelas beaker, gelas ukur, blender, dan plastik klip. Alat untuk analisis karakteristik nori yaitu: oven (Memmert, Jerman), Kjeldahl apparatus (FOSS, Denmark), muffle furnace (TMAXKFB1100, China), dan texture analyzer (Brookfield, AS).

Penelitian menggunakan metode experimental laboratories. Rancangan percobaan yang digunakan adalah Rancangan Acak Lengkap (RAL) dengan pola $3 \times 3$. Penelitian ini menggunakan perlakuan perbedaan perbandingan $U$. lactuca dan 
Gelidium yaitu 75:25\% (P1); 50:50\% (P2) dan 25:75\% (P3).

\section{Metode Penelitian \\ Preparasi sampel}

Rumput laut yang digunakan adalah rumput laut kering. Rumput laut yang sudah bersih kemudian direndam 24 jam untuk Gelidium dan 6 jam untuk U. lactuca. Larutan asam asetat $2 \%$ digunakan untuk merendam rumput laut selama 30 menit. Rumput laut dihaluskan dengan blender dan ditimbang sebanyak 100 g. Selanjutnya rumput laut ditambahkan dengan akuades dengan perbandigan 1:1 untuk $U$. lactuca dan 1: 9 untuk Gelidium. Rumput laut U. lactuca dimasak di atas kompor dengan suhu 90$100^{\circ} \mathrm{C}$ selama 30 menit dan Gelidium selama 2 jam. Rumput laut kemudian dicampurkan sesuai dengan perlakuan perbandingan berat. Adonan kemudian dicetak diatas loyang aluminium yang sudah dialasi dengan kertas aluminium dan dikeringkan dalam oven selama 8 jam dengan suhu $70^{\circ} \mathrm{C}$. Hal ini merujuk pada penelitian Sari et al. (2017) yaitu pada percobaan pengeringan rumput laut didapatkan kondisi optimum terjadi pada penggunaan suhu $70^{\circ} \mathrm{C}$.

\section{Prosedur analisis}

Uji hedonik mengacu pada SNI 01-23462006 tentang petunjuk pengujian organoleptik atau sensori. Pengujian kadar air, protein, abu, dan serat berdasar pada AOAC (2005).

Kuat tarik mengacu pada metode Rusli et al. (2017), menggunakan Universal Testing Machine (Texture Analyzer). Nori dipotong dengan panjang $50 \mathrm{~mm}$ dan lebar 5 $\mathrm{mm}$. Kuat tarik (MPa) dihitung berdasarkan gaya maksimal (Newton) yang diberikan pada film sampai putus dibagi dengan luas film $\left(\mathrm{m}^{2}\right)$.

\section{Analisis data}

Data parametrik berupa kuat tarik, kadar air, protein, dan abu yang diperoleh dianalisis kenormalan serta sidik ragam (ANOVA) dan dilanjutkan dengan uji beda rerata menggunakan analisis Tukey apabila perlakuan nyata. Analisis statistika dilakukan dengan menggunakan SPSS 16.

\section{HASIL DAN PEMBAHASAN Uji Hedonik Nori}

Nilai hedonik merupakan salah satu metode pengujian mutu hasil perikanan yang prinsip dan teknis pelaksanaannya sangat sederhana. Metode pengujian hedonik didasarkan atas kesukaan konsumen terhadap suatu produk. Teknis pelaksanaannya konsumen diminta memberi penilaian terhadap suatu produk. Hasil pengujian hedonik nori pada dengan perlakuan perbedaan berat $U$. lactuca dan Gelidium tersaji pada Table 1 .

\section{Kenampakan}

Dalam uji hedonik, parameter kenampakan menunjukkan keadaan tampak dan memberikan kesan kepada konsumen pada saat melihat suatu produk. Kenampakan nori dari P1 hampir sama dengan nori P2 yaitu berbentuk lembaran tipis dan mengkilap sedangkan nori dari P3 berbentuk lembaran tipis, berpori dan kasar pada permukaannya.

Kenampakan nori yang paling disukai panelis adalah nori $\mathrm{P} 1$ (75\% U. lactuca dengan $25 \%$ Gelidium) dengan kenampakan nori berbentuk lembaran tipis mirip kertas yang mengkilap, utuh, rata dengan ukuran 19x19 $\mathrm{cm}^{2}$. Kenampakan nori dari perlakuan satu hampir sama dengan nori perlakuan dua yaitu berbentuk lembaran tipis dan mengkilap. Kenampakan nori P2 $(50 \%$ U. lactuca dan $50 \%$ Gelidium) disukai panelis sedangkan

Table 1 Hedonic value of nori made from different ratios of Ulva lactuca and Gelidium

\begin{tabular}{lcccccc}
\hline Sample & Appearance & Odor & Taste & Texture & Color & Total \\
\hline P1 & $7.9 \pm 0.77^{\mathrm{a}}$ & $6.9 \pm 1.08^{\mathrm{a}}$ & $6.7 \pm 1.4^{\mathrm{a}}$ & $7.5 \pm 1.0^{\mathrm{a}}$ & $7.7 \pm 0.74^{\mathrm{a}}$ & $7.2<\mu<7.4^{\mathrm{a}}$ \\
P2 & $7.3 \pm 0.66^{\mathrm{b}}$ & $6.4 \pm 0.85^{\mathrm{b}}$ & $6.3 \pm 1.2^{\mathrm{a}}$ & $6.8 \pm 0.6^{\mathrm{b}}$ & $7.0 \pm 0.61^{\mathrm{b}}$ & $6.6<\mu<6.9^{\mathrm{b}}$ \\
P3 & $5.7 \pm 0.11^{\mathrm{c}}$ & $6.1 \pm 0.81^{\mathrm{c}}$ & $4.6 \pm 1.3^{\mathrm{b}}$ & $5.4 \pm 1.0^{\mathrm{c}}$ & $5.5 \pm 0.59^{\mathrm{c}}$ & $5.3<\mu<5.7 \mathrm{c}$ \\
\hline
\end{tabular}

Note: P1: 75\% Ulva lactuca: 25\% Gelidium; P2: 50\% Ulva lactuca: 50\% Gelidium; P3: 25\% Ulva lactuca: 75\% Gelidium; Different letters in the same column indicate significant differences $(p<0.05)$. 


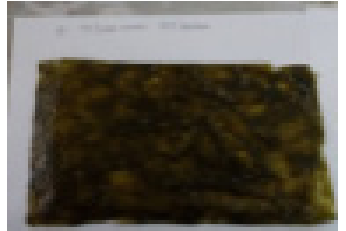

(A)

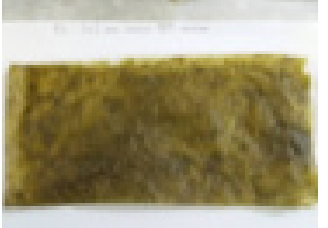

(B)

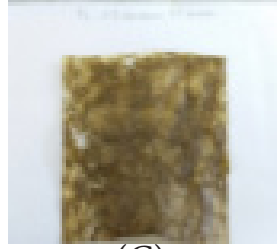

(C)

Figure 1 Appearance of nori with different ratio between U. lactuca and Gelidium; (A) 75\%:25\%;

(B) $50 \%: 50 \%$; (C) 25\%:75\%.

kenampakan nori P3 (25\% U. lactuca dan $75 \%$ Gelidium) agak tidak disukai panelis dengan kenampakan berbentuk lembaran tipis, berpori dan kasar pada permukaannya. Komposisi Gelidium yang semakin besar memberikan kenampakan nori yang semakin tidak disukai panelis. Menurut Winarno (1996), agar akan berikatan dengan air dan menghasilkan gel yang kaku serta keras. Kenampakan nori dengan komposisi Gelidium lebih besar memberikan kenampakan nori yang terlalu keras dan kaku sehingga kurang disukai panelis.

\section{Aroma}

Perlakuan perbandingan berat U. lactuca dengan Gelidium memberikan pengaruh nyata $(p<0,05)$ pada nilai bau nori. Nori hasil penelitian memiliki bau yang agak amis dan spesifik rumput laut. Secara umum nori komersial juga memiliki bau yang spesifik rumput laut. Bau yang dihasilkan dari nori U. lactuca dan Gelidium juga dipengaruhi oleh pembumbuan yang dilakukan dalam proses pembuatannya. Bumbu yang ditambahkan selama proses pembuatan berupa minyak wijen dan saus tiram dapat mengurangi bau amis pada nori. Kombinasi asam amino dari rumput laut dan bumbu memberi kontribusi terhadap nilai rasa maupun aroma nori. Hasil pengujian bau nori menunjukkan bahwa nori yang memiliki bau paling disukai konsumen adalah nori P1. Nori P1memiliki bau yang spesifik rumput laut dan disukai panelis. Nori P2 disukai oleh panelis dan nori P3 agak disukai panelis.

\section{Rasa}

Uji hedonik terhadap rasa nori menunjukkan yang paling disukai oleh panelis adalah nori pada P1 dengan rasa cukup enak dan asin. Nori P2 dan P3 agak tidak disukai panelis. Nori komersial memiliki rasa asin, gurih dan spesifik rumput laut. Nori dengan komposisi U.lactuca lebih besar (P1) lebih disukai panelis karena Ulva sp. mengandung sejumlah besar asam amino sisteinolik, asam sisteik, pralin, asam glutamat dan chondrine (Lalopua 2017). Menurut Riyanto et al. (2014), rasa lezat (umami) nori dikarenakan kandungan free amino acid seperti alanin, asam glutamat, taurin, dan asam aspartat. Asam amino tersebut berperan dalam menciptakan rasa nori yang enak (umami).

\section{Tekstur}

Tekstur yang dihasilkan dari nori P1 memiliki tektur yang halus, tipis, elastis, dan mudah dilipat. Nori ini memiliki tekstur berserat dan mudah dikonsumsi. Hal ini menunjukkan nori dapat digunakan sebagai pembungkus nasi. Nori P3 yang dihasilkan dari $25 \%$ U. lactuca dengan $75 \%$ Gelidium memiliki tekstur yang kasar, keras dan berpori-pori. Nori pada perlakuan ketiga ini sangat sulit untuk dikunyah karena teksturnya yang keras. Nori P3 juga sulit untuk dilipat dan digulung. Lembarannya akan patah saat dilipat atau digulung. Semakin tinggi jumlah Gelidium yang ditambahkan semakin mudah nori dibentuk namun teksturnya semakin kasar dan keras. Nori hasil penelitian mudah dibentuk karena kandungan polisakarida jenis agar yang dikandung Gelidium. Menurut Ramnani et al. (2012) alga merah Gracillaria dan Gelidium umumnya terdiri dari struktur polisakarida agar disusun oleh D-galaktosa yang berikatan 1,3 dengan 3,6-anhidrogalaktosa dan rantai 3,6-anhidrogalaktosa yang berikatan secara 1,4 dengan D-galaktosa. 


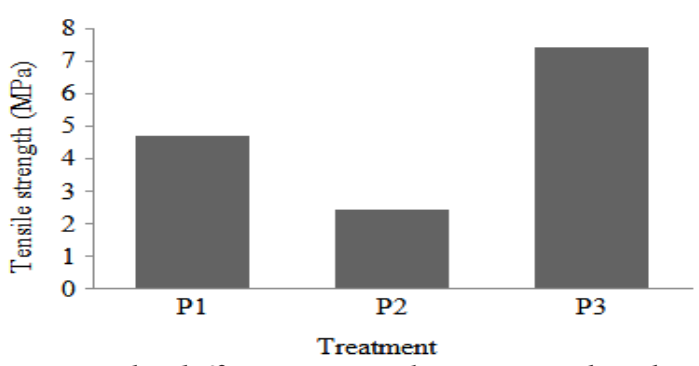

Figure 2 Tensile strength of nori with different ratio between Ulva lactuca and Gelidium; P1 (75\%:25\%); P2(50\%:50\%); P3 (25\%:75\%)

\section{Warna}

Warna yang dihasilkan dari nori P1 berwarna hijau pekat sedangkan nori dengan dua perlakuan lain memiliki warna hijau kekuningan. Nori P1 menghasilkan warna yang paling mirip dengan nori komersial yang berwarna hijau gelap. Dari hasil pengujian hedonik warna dapat diketahui persentase $U$. lactuca yang semakin besar memberikan warna yang lebih disukai panelis. Warna nori dipengaruhi oleh kandungan pigmen dan waktu pengeringan nori. Nori yang berwarna hijau disebabkan oleh kandungan pigmen klorofil yang terdapat pada U. lactuca. Abirami dan Kowsalya (2011) menyebutkan bahwa $U$. lactuca merupakan alga hijau yang memiliki kandungan klorofil yang tinggi dan lebih banyak dari alga merah. Alga hijau mengandung klorofil a dan klorofil b dan beberapa di antaranya adalah $U$. lactuca.

\section{Kuat Tarik Nori}

Kuat tarik adalah regangan maksimal yang masih dapat diterima oleh sampel sebelum putus. Hasil dari nilai kuat tarik nori dapat dilihat pada Figure 2.

Hasil uji kekuatan tarik nori dengan perlakuan perbandingan berat $U$. lactuca dan Gelidium dihasilkan nilai antara 2,42 MPa-7,3 MPa. Nilai kuat tarik tertinggi terdapat pada nori $\mathrm{P} 3$ dengan perbandingan $25 \%$ U. lactuca dan $75 \%$ Gelidium. Hal ini dikarenakan kandungan agar yang dihasilkan dari Gelidium lebih tinggi dibandingkan dua perlakuan lainnya. Agar-agar mengandung dua komponen yaitu agarosa dan agaropektin. Agarosa merupakan komponen pembentuk gel. Besarnya kandungan agarosa dalam agar mengakibatkan semakin meningkatnya kekuatan gel dari agar sehingga meningkatkan kuat tarik nori. Lalopua (2018) menjelaskan bahwa peningkatan kekuatan tarik diduga dikarenakan adanya ikatan hidrogen antar molekul $\mathrm{CH}_{2} \mathrm{OH}$ pada struktur agar dan $\mathrm{OH}$ - pada air yang saling berinteraksi. Reaksi tersebut akan memutus ikatan $\mathrm{CH}_{2} \mathrm{OH}$ yang menyebabkan terbentuknya rantai $\mathrm{OH}$ - yang panjang sehingga dapat meningkatkan kuat tarik lembaran nori.

\section{Kadar Serat Kasar Nori}

Serat kasar adalah semua serat yang tidak dapat dicerna. Komponen serat kasar ini terdiri dari selulosa, lignin, pentosa, dan komponen-komponen lainnya. Hasil dari nilai serat kasar nori dapat dilihat pada Figure 3

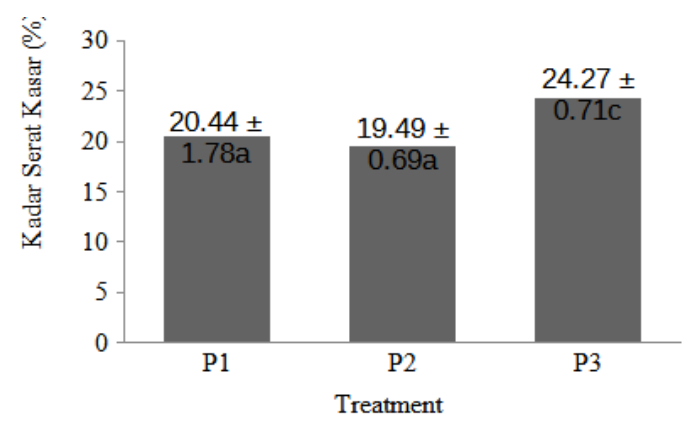

Figure 3 Crude fiber of nori made from different ratios of Ulva lactuca and Gelidium; P1 (75\%:25\%); P2(50\%:50\%); P3 (25\%:75\%). 
Table 2 Proximate of nori made from different ratios of Ulva lactuca and Gelidium

\begin{tabular}{lccccc}
\hline & & \multicolumn{2}{c}{ Protein (\%) } & \multicolumn{2}{c}{ Ash (\%) } \\
\cline { 3 - 6 } Sample & Moisture (\%) & $\begin{array}{c}\text { Wet basis } \\
(\mathrm{wb})\end{array}$ & $\begin{array}{c}\text { Dry basis } \\
(\mathrm{db})\end{array}$ & $\begin{array}{c}\text { Wet basis } \\
(\mathrm{wb})\end{array}$ & $\begin{array}{c}\text { Dry basis } \\
(\mathrm{db})\end{array}$ \\
\hline P1 & $17.24 \pm 0.57^{\mathrm{a}}$ & $12.89 \pm 0.07^{\mathrm{a}}$ & $74.76 \pm 0.07^{\mathrm{a}}$ & $14.71 \pm 0.09^{\mathrm{a}}$ & $16.76 \pm 0.09^{\mathrm{a}}$ \\
P2 & $17.00 \pm 0.38^{\mathrm{a}}$ & $11.76 \pm 0.06^{\mathrm{b}}$ & $69.17 \pm 0.06^{\mathrm{b}}$ & $13.07 \pm 0.29^{\mathrm{b}}$ & $15.74 \pm 0.29^{\mathrm{b}}$ \\
P3 & $16.7 \pm 0.39^{\mathrm{a}}$ & $11.34 \pm 0.04^{\mathrm{c}}$ & $67.90 \pm 0.04^{\mathrm{c}}$ & $11.44 \pm 0.25^{\mathrm{c}}$ & $13.73 \pm 0.25^{\mathrm{c}}$ \\
\hline
\end{tabular}

Note: P1: 75\% Ulva lactuca: 25\% Gelidium; P2: 50\% Ulva lactuca: 50\% Gelidium; P3: 25\% Ulva lactuca: 75\% Gelidium; Different letters in the same column indicate significant differences $(p<0.05)$; Values are presented as mean \pm SD $(\mathrm{n}=3)$.

Hasil dari sidik ragam menunjukkan bahwa perlakuan perbandingan berat U. lactuca dengan Gelidium memberikan pengaruh nyata terhadap kadar serat kasar nori. Hasil pengujian kadar serat kasar nori dihasilkan nilai antara 19,49-24,27\%. Kadar serat kasar tertinggi dimiliki nori $\mathrm{P} 3$ dengan perbandingan $25 \% \quad U$. lactuca dan $75 \%$ Gelidium. Kadar serat kasar salah satunya dipengaruhi oleh kandungan air. Penurunan kadar serat kasar diakibatkan oleh peningkatan kadar air suatu bahan (Sari et al. 2015). Nori P3 memiliki kandungan air terendah di antara dua perlakuan lainnya.

\section{Kadar Proksimat Nori}

Hasil Pengujian proksimat (kadar air, protein, dan abu) pada nori dengan perlakuan perbandingan U. lactuca dengan Gelidium tersaji pada Table 2.

\section{Kadar protein}

Perbedaan perbandingan rumput laut U. lactuca dengan Gelidium memberikan pengaruh nyata terhadap nilai kadar protein $(p<0,05)$. Kadar protein yang didapat dari nori campuran U. lactuca dengan Gelidium yaitu 11,34-12,89\%. Nilai kadar protein tertinggi dihasilkan dari nori P1 yaitu dengan $75 \%$ U. lactuca dan $25 \%$ Gelidium, sedangkan kandungan protein terendah pada nori P3 dengan $25 \%$ U. lactuca dan $75 \%$ Gelidium. Nilai protein nori penelitian lebih rendah dari nori komersial. Nori komersial memiliki kandungan protein mencapai $25-50 \%$ berat kering (Kayama et al.1985 dalam Murdinah 2007). Rendahnya kadar protein nori pada penelitian ini kemungkinan disebabkan proses perendaman U. lactuca dan Gelidium dalam larutan asam asetat menyebabkan sebagian protein terlarut. Muthmainna et al. (2016) menjelaskan bahwa protein memiliki sifat mudah larut dalam larutan garam dan asam cair serta mudah terdenaturasi oleh suhu. Denaturasi protein berakibat pada kerusakan protein, sehingga semakin tinggi protein yang terdenaturasi berakibat pada semakin rendah kadar protein.

\section{Kadar air}

Perlakuan perbedaan perbandingan rumput laut U. lactuca dan Gelidium tidak memberikan pengaruh nyata $(p>0,05)$ terhadap nilai kadar air. Nilai kadar air nori U. lactuca dan Gelidium berkisar antara 16,717,24\%. Nori P1 memiliki kadar air paling tinggi, sedangkan nori P3 memiliki kadar air terendah. Nori komersial diketahui memiliki kandungan air sebesar 8,44\% (Riyanto et al. 2014). Nilai ini lebih kecil dibandingkan nori hasil penelitian. Tingginya kandungan air nori U. lactuca dan Gelidium disebabkan karena kandungan agar pada Gelidium mampu meningkatkan kemampuan mengikat air sehingga menyebabkan produk nori ini mudah mengikat air sehingga kadar air menjadi tinggi. Widyaningtyas dan Wahono (2015) menjelaskan bahwa penambahan hidrokoloid yang semakin tinggi akan meningkatkan kekompakan matrik gel. Gel yang terbentuk semakin kuat dan air yang terikat semakin banyak sehingga selama proses pengeringan air yang menguap semakin kecil. Hal tersebut menyebabkan kadar air menjadi lebih tinggi.

\section{Kadar abu}

Hasil uji ANOVA didapatkan nilai $p<0,05$. Hal ini menunjukkan bahwa 
perbandingan setiap perlakuan memberikan pengaruh nyata terhadap nilai kadar abu. Nilai kadar abu nori U. lactuca dengan Gelidium yaitu antara $11,44-14,71 \%$. Nori P1 memiliki kadar abu paling tinggi sedangkan nori P3 memiliki kadar abu paling rendah. Kadar abu terkait erat dengan kadar mineral pada suatu bahan. Hal ini menunjukkan bahwa nori pada perlakuan pertama memiliki mineral lebih besar dibandingkan dua perlakuan lainnya. Nilai kadar abu nori penelitian lebih besar dibandingkan nori komersial. Nori komersial memiliki kadar abu antara 8,789,07\% (Hwang et al. 2013). Adanya perbedaan kadar abu dapat terjadi karena perbedaan spesies rumput laut yang digunakan, habitat tempat tumbuh rumput laut tersebut, dan cara pengolahan atau prosedur yang diterapkan.

\section{KESIMPULAN}

Proses pembuatan nori dengan perlakuan perbandingan persentase $U$. lactuca dan Gelidium berpengaruh nyata $(p<0.05)$ terhadap nilai hedonik, kuat tarik, kadar serat kasar, protein dan abu, namun tidak berpengaruh nyata terhadap kadar air $(p>0,05)$. Penggunaan $U$. lactuca dan Gelidium sebagai bahan baku mempengaruhi karakteristik nori. Semakin banyak jumlah Gelidium yang digunakan nori semakin mudah dibentuk namun keras, kaku dan berongga. Semakin besar jumlah $U$. lactuca yang digunakan semakin tinggi kadar air, sehingga nori tidak renyah. Perlakuan P1 $(75 \%$ U. lactuca dan 25\% Gelidium) adalah nori yang paling disukai panelis dan mempunyai karakteristik warna hijau tua, mudah dilipat, tipis, memiliki tekstur yang halus dan rasa asin, mendekati nori komersial dengan nilai hedonik tertinggi.

\section{DAFTAR PUSTAKA}

[AOAC] Association of Official Analytical Chemist. 2005. Official Method of Analysis of the Association of Official Analytical of Chemist. Virginia (US): The Association of Analytical Chemist, Inc.

Abdulah DR, Liviawaty E, Iskandar, Afrianto E. 2019. The level of nori's relief made from raw seaweed mixed Gelidium sp. and Eucheuma cottonii. Asian Food Science Journal. 11(3): 1-9.
Abirami RG, Kowsalya S. 2011. Nutrient and nutraceutical potentials of seaweed biomass Ulva lactuca and Kappaphycus alvarezii. Journal of Agricultural Scienceand Technology. 5(1): 109-115.

Abraham A, Afewerki B, Tsegay B, Ghebremedhin H, Teklehaimanot B, Reddy KS. 2018. Extraction of agar and alginate from marine seaweeds in red sea region. International Journal of Marine Biology and Research. 3(2): 1-8.

Anton. 2017. Pertumbuhan dan kandungan agar rumputlaut (Gracillaria spp) pada beberapa tingkat salinitas. Jurnal Airaha. 6(2): $054-64$.

Arbi B, Ma'ruf WF, Romadhon. 2016. Aktivitas senyawa bioaktif selada laut (Ulva lactuca) sebagai antioksidan pada minyak ikan. Saintek Perikanan. 12(1): 12-18.

Dewi R. 2012. Potensi sumberdaya rumput laut. Jurnal Harpodon Borneo. 5(2): 125129.

Erniati, Zakaria FR, Prangdimurti E, Adawiyah DR, Priosoeryanto BP. 2018. Penurunan logam berat dan pigmen pada pengolahan geluring rumput laut Gelidium sp. dan Ulva Lactuca. Jurnal Pengolahan Hasil Perikanan Indonesia. 21(2): 266-275.

Fajarini LDR, Ekawati GA, Ina PT. 2018. Pengaruh penambahan karagenan terhadap karakteristik permen jelly kulit anggur hitam (Vitis vinifera). Jurnal ITEPA. 7(2):43- 52

Faris A, Liviawaty E, Andriani Y, Affrianto E. 2019. Nori level of preference with mixed Sargassum sp. and Eucheuma spinosum seaweed as raw material. Asian Food Science Journal. 11(2), 1-9.

Fitrah SK, Sumartini DS, Achyadi NS. 2019. Kajian Perbandingan Rumput Laut (Gracilaria sp) dengan Belut (Monopterus albus) Serta Suhu Pengeringan Terhadap Karakteristik Snack Nori. [Skripsi]. Bandung (ID): Universitas Pasundan.

Hussein MH. 2015. Extraction of agar from Gelidium (Rhodophyta) and green synthesis of agar/silver nano particles. Journal of Agricultural Chemical and Biotechnology. 6 (10): 419 - 434, 2015

Hwang ES, Ki KN, Chung HY. 2013. Proximate 
composition, amino acid, mineral, and heavy metal content of dried laver. Nutrition Food Science. 18(2):139-144.

Kurniawan K, Bintoro N. 2019. Engineering analysis in manufacturing process of nori made from mixture of Ulva lactuca and Gracillaria sp. IOP Conf. Series: Earth and Environmental Science 355 (2019) 012036. The 3rd International Symposium on Agricultural and Biosystem Engineering 6-8 August 2019, South Sulawesi, Indonesia.

Kurniawan R, Nurjanah, Jacoeb AM, Abdullah A, Pertiwi RM. 2019. Karakteristik garam fungsional dari rumput laut hijau. Jurnal Pengolahan Hasil Perikanan Indonesia. 22(3): 573-580.

Lalopua VMN. 2017. Pemanfaatan dan karakteristik nori tiruan menggunakan bahan baku alga Hypnea saidana dan Ulva conglubata dari perairan Maluku. Majalah Biam. 13(02): 33-40.

Lalopua VMN. 2018. Karakteristik fisik kimia nori rumput laut merah Hypnea saidana menggunakan metode pembuatan berbeda dengan penjemuran matahari. Majalah Biam.14(01): 28-36

Lebbar S, Fanuel M, Le Gall S, Falourd X, Ropartz D, Bressollier P, Gloaguen V, Faugeron-Girard. 2018. Agar Extraction By-Products from Gelidium sesquipedale as a Source of Glycerol-Galactosides. Molecules. 23, 3364: 1-8.

Luthfiyana N, Nurjanah, Nurilmala M, Anwar E, Hidayat T. 2016. Rasio bubur rumput laut Euchema cottonii dan Sargassum sp. sebagai formula krim tabir surya. Jurnal Pengolahan Hasil Perikanan Indonesia. 19(3): 183-195

Murdinah D, Fransiska, dan Subaryono. 2008. Pembuatan bakso agar dari rumput laut Gelidium rigidum untuk media tumbuh bagi mikroorganisme. Jurnal Pascapanen dan Bioteknologi Kelautan dan Perikanan. 3(1): 79-88.

Muthmainna, Sabang SM, Supriadi. 2016. Pengaruh waktu fermentasi $t \mathrm{e} r \mathrm{~h}$ a d a $\mathrm{p}$ kadar protein dari tempe biji buah lamtorogung (Leucaena leucocephala).
Jurnal Akademika Kimia. 5(1): 50-54.

Nufus C, Nurjanah, Abdullah A. 2017. Karakteristik rumput laut hijau dari perairan Kepulauan Seribu dan Sekotong Nusa Tenggara Barat sebagai antioksidan. Jurnal Pengolahan Hasil Perikanan Indonesia. 20(3): 620-632.

Nurjanah, Abdullah A, Nufus C. 2018 Karakteristik sediaan garam Ulva lactuca dari perairan sekotong Nusa Tenggara Barat bagi pasien hipertensi. Jurnal Pengolahan Hasil Perikanan Indonesia. 21(1): 109-117.

Ramnani P, Chitarrari R, Tuohy K, Grant J, Hotchkiss S, Philp K, Campbell R, Rowland GC. 2012. In vitro fermentation and prebiotic potential of novel low molecular weight polysaccharides derived from agar and alginate seaweeds. Asian Pacific Journal of Tropical Biomedicine. 5(6): 345-349.

Rismandari M, Agustini TW, Amalia U. 2017. Karakteristik permen jelly dengan penambahan iota karagenan dari rumput laut Eucheuma spinosum. Saintek Perikanan. 12(2) : 103-108.

Riyanto B, Trilaksani W, Susyiana LE. 2014. Nori imitasi lembaran dengan konsep edible film berbasis protein myofibrillar ikan nila. Jurnal Pengolahan Hasil Perikanan Indonesia. 17(3): 263-280.

Sari DK, Kustiningsih I, Lestari RSD.2017. Pengaruh Suhu dan Waktu Pengeringan Terhadap Mutu Rumput Laut Kering. Jurnal Teknika.13(1):43-50.

Widyaningtyas M, Wahono H. 2015. Pengaruh jenis dan konsentrasi hidrokoloid (carboxymethyl cellulose, xanthan gum dan karagenan) terhadap karakteristik mie kering berbasis pasta ubi jalar varietas ase kuning. Jurnal Pangan dan Agroindustri. 3(2): 417-423.

Zakaria FR, Priosoeryanto BP, Erniati, Sajida. 2017. Karakteristik nori dari campuran rumput laut Ulva lactucadan Eucheuma cottonii. Jurnal Pasca panen dan Bioteknologi Kelautan dan Perikanan.12 (1): 23-30. 